\title{
Mackenzie Inuit Lithic Raw Material Procurement in the Lower Mackenzie Valley: The Importance of Social Factors
}

\author{
GLEN MacKAY, ${ }^{1}$ ADRIAN L. BURKE, ${ }^{2}$ GILLES GAUTHIER ${ }^{3}$ and CHARLES D. ARNOLD ${ }^{4}$
}

(Received 5 July 2012; accepted in revised form 1 April 2013)

\begin{abstract}
Oral and written historical records indicate that the Mackenzie Inuit traveled up the Mackenzie River from the Arctic Coast to procure lithic raw material in the interior from a quarry at the mouth of the Thunder River, which is known locally by the Gwich'in of the lower Mackenzie Valley as Vihtr'ii Tshik. We evaluate this proposition using non-destructive polarized energy dispersive X-ray fluorescence to compare the geochemical signatures of the lithic raw material from Vihtr'ii Tshik (MiTi-1) and flakes and tools from the Mackenzie Inuit village of Kuukpak (NiTs-1), which is located more than $400 \mathrm{~km}$ downriver of the quarry source. The concentrations of nine selected elements - three major elements expressed as oxides $\left(\mathrm{SiO}_{2}, \mathrm{Fe}_{2} \mathrm{O}_{3} \mathrm{~T}\right.$, and $\left.\mathrm{K}_{2} \mathrm{O}\right)$ and six trace elements expressed as metals ( $\mathrm{Rb}, \mathrm{Sr}, \mathrm{Y}, \mathrm{Zr}, \mathrm{Ba}$, and $\mathrm{Ce}$ ) — are compared using descriptive statistics, spider diagrams, and principal components analysis. The geochemical effects of chemical weathering on the surfaces of artifacts are evaluated by measuring element concentrations before and after removal of the weathering rind from select artifacts. The results of our analyses demonstrate that the lithic raw material available at Vihtr'ii Tshik is best characterized as chert, and that $86 \%$ of the flakes and tools from Kuukpak analyzed in this study are chemically similar to the raw material from Vihtr'ii Tshik. Historical records and archaeological data indicate that the people of Kuukpak traversed a complex social landscape to obtain stone from Vihtr'ii Tshik through direct procurement.
\end{abstract}

Key words: geochemical analysis, energy dispersive X-ray fluorescence, Mackenzie Inuit, Dene, Kuukpak, lithic raw material procurement, quarry sites, Thunder River chert, oral history

RÉSUMÉ. Les traditions orales et écrites historiques indiquent que les Inuits du Mackenzie remontaient le fleuve Mackenzie en quittant la côte arctique et allant vers l'intérieur des terres afin d'obtenir de la matière première lithique d'une carrière qui se trouvait près de l'embouchure de la rivière Thunder. Les Gwich'in de la basse vallée du Mackenzie appellent cet endroit Vihtr'ii Tshik. Nous évaluons ces révélations en utilisant la technique de fluorescence par rayons $\mathrm{X}$ en mode dispersion d'énergie (géométrie polarisante, méthode non destructive) afin de comparer les signatures géochimiques des roches trouvées à la carrière Vihtr'ii Tshik (MiTi-1) avec celles des éclats et des outils en pierre provenant d'un site villageois inuit appelé Kuukpak (NiTs-1) qui se trouve à $400 \mathrm{~km}$ en aval de la carrière. Les concentrations de neuf éléments chimiques - trois éléments majeurs exprimés sous la forme d'oxydes $\left(\mathrm{SiO}_{2}, \mathrm{Fe}_{2} \mathrm{O}_{3} \mathrm{~T}\right.$ et $\left.\mathrm{K}_{2} \mathrm{O}\right)$ et six éléments traces exprimés sous la forme de métaux $(\mathrm{Rb}$, $\mathrm{Sr}, \mathrm{Y}, \mathrm{Zr}, \mathrm{Ba}$ et $\mathrm{Ce}$ ) - sont utilisées pour calculer des statistiques descriptives et des diagrammes-araignées, et réaliser une analyse multivariée par composantes principales. Nous évaluons aussi les effets géochimiques causés par l'intempérisation de la surface des artefacts en mesurant les concentrations d'éléments avant et après l'enlèvement de celle-ci sur des artefacts sélectionnés. Les résultats de nos analyses chimiques démontrent que la roche provenant de la carrière Vihtr'ii Tshik est un chert, et que $86 \%$ des éclats et outils analysés dans cette étude provenant du site villageois Kuukpak montrent des affinités géochimiques au chert de cette carrière. Les documents historiques et les données archéologiques nous indiquent que les gens de Kuukpak devaient naviguer à travers une géographie culturelle complexe afin de se procurer directement le chert de la carrière de Vihtr'ii Tshik.

Mots clés : analyse géochimique, fluorescence par rayons $\mathrm{X}$ en mode dispersion d'énergie, Inuits du Mackenzie, Déné, Kuukpak, économie des matières premières lithiques, carrières, chert de la rivière Thunder, traditions orales

Révisé par la revue Arctic par Nicole Giguère.

\footnotetext{
${ }^{1}$ Prince of Wales Northern Heritage Centre, PO Box 1320, Yellowknife, Northwest Territories X1A 2L9, Canada; Glen_MacKay@gov.nt.ca

${ }^{2}$ Département d'anthropologie, Université de Montréal, CP 6128, succursale Centre-ville, Montréal, Québec H3C 3J7, Canada

${ }^{3}$ Département de Chimie, Université de Montréal, CP 6128, succursale Centre-ville, Montréal, Québec H3C 3J7, Canada

${ }^{4}$ Department of Archaeology, University of Calgary, 2500 University Dr. NW, Calgary, Alberta T2N 1N4, Canada

(C) The Arctic Institute of North America
} 


\section{INTRODUCTION}

In recent decades, archaeologists working in Canada's North have attempted to situate lithic quarries in ancient social and cultural landscapes. Many of the quarries in this region are considered sacred places by Aboriginal peoples, and oral traditions record specific cultural protocols, often involving ritual offerings to the spirits inhabiting quarry areas, to be followed when extracting stone (Pokotylo and Hanks, 1989; Andrews and Zoe, 1997; Andrews et al., 2012). In turn, the cultural significance of certain quarries and the stone extracted from them informed the lithic procurement choices of northern hunter-gatherer societies (Loring, 1992; McCaffrey, 2011). For example, Loring (1992) suggests that the almost exclusive use of Ramah chert in Daniel Rattle complex sites on the coast of Labrador reflects strong ideas of social identity linked to the procurement and use of this material, which explains why it was favored over other sources of stone located closer to these sites.

As fixed resources in dynamic social landscapes, many northern quarries were also places of increased social interaction between different peoples. For example, the oral traditions of the Sambaa K'e Got'ine (Trout Lake People) of the southwestern Northwest Territories tell of a lithic quarry with a place name that translates to "killing each other for it" (MacKay, 2010). The stories about this place suggest that people had to sneak into this quarry at night to avoid hostile encounters with other groups. In some cases, the formation of social alliances facilitated lithic procurement through direct access to quarries or trade networks, while in others, the development of social barriers disrupted long-standing procurement patterns (Loring, 1992; McCaffrey, 2011). The Thule expansion into coastal Labrador, for example, may have limited the access of other groups in this region to Ramah chert (Loring, 1992).

In this paper, we explore how social factors related to the presence of others shaped hunter-gatherer procurement at a lithic quarry in the lower Mackenzie Valley of Canada's Northwest Territories. This quarry provides an ideal setting for investigating the social dimensions of lithic procurement because early written historical sources indicate that it was used by both Inuit and Dene (Athapaskan) groups at the time of contact with European explorers. In his journal entry for 24 July 1789, Alexander Mackenzie noted that his party had passed a small river "at each side of wch the Natives and Eskmeaux get Flint" (Lamb, 1970:209). Archaeological investigations in the lower Mackenzie Valley have identified the place that Mackenzie refers to as a lithic quarry at the mouth of the Thunder River, which is known locally as Vihtr'ii Tshik - a Gwich'in place name that translates to 'flint at the mouth of' (Pilon, 1990; Pokotylo, 1994; Gwich'in Social and Cultural Institute, 2012; Fig. 1). At first glance, Mackenzie's reference to Inuit use of Vihtr'ii Tshik as a lithic source is somewhat surprising. Vihtr'ii Tshik is located more than $400 \mathrm{~km}$ upriver from the Arctic Coast and lies deep within the traditional use area

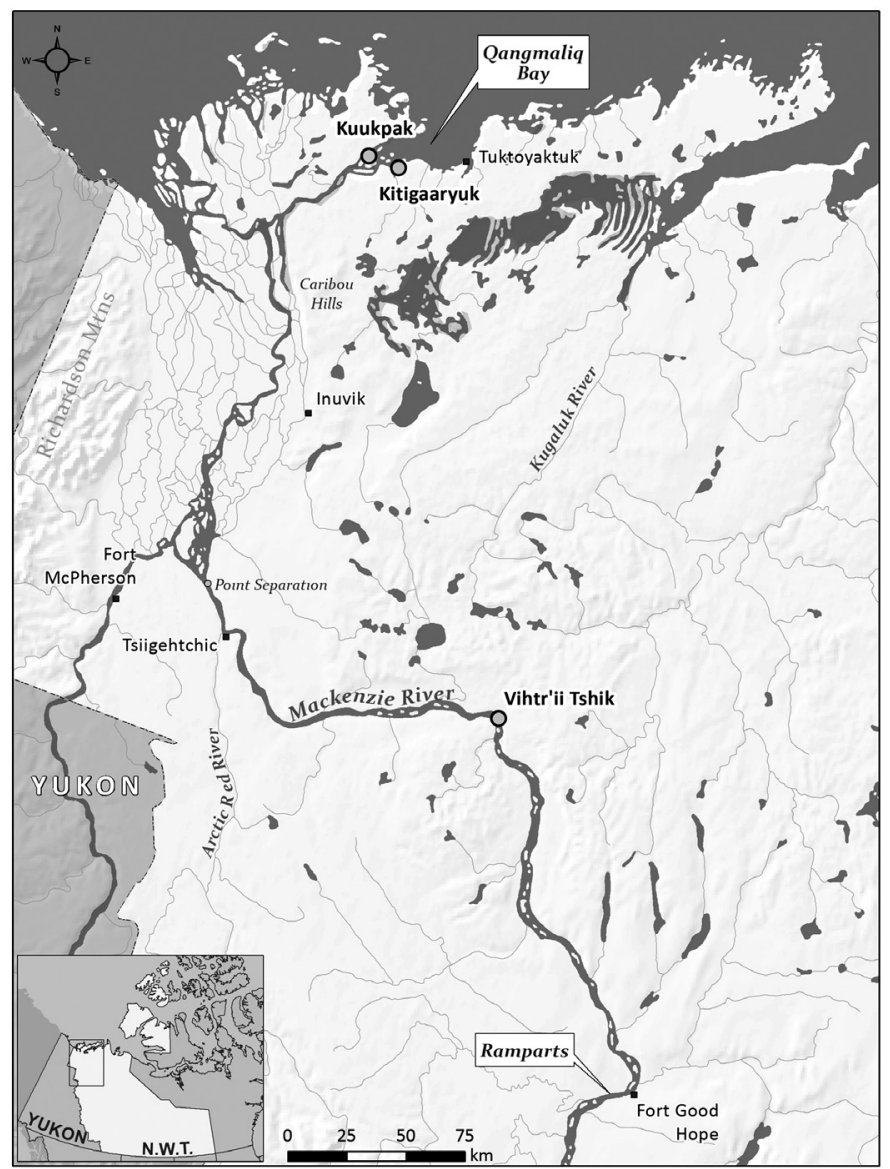

FIG. 1. Map showing the locations of Kuukpak, Vihtr'ii Tshik, and other places mentioned in the text.

of the Dene, who we might expect would have acted as a social barrier to long-distance travel upriver by Inuit groups (Fig. 1). Indeed, the oral traditions of two Dene societiesthe Gwichya Gwich'in, who today live primarily in the community of Tsiigehtchic, and the K'asho Got'ine, many of whom now live in the community of Fort Good Hopeindicate that these groups also procured stone from Vihtr'ii Tshik. The first step in our analysis is to test the hypothesis that the Mackenzie Inuit obtained stone from Vihtr'ii Tshik using archaeological data. We use energy-dispersive X-ray fluorescence to compare the geochemical signatures of the lithic raw material from Vihtr'ii Tshik (MiTi-1) and flakes and tools from the Mackenzie Inuit village of Kuukpak (NiTs-1), which is located in the estuary of the East Channel of the Mackenzie River approximately $400 \mathrm{~km}$ downstream of Vihtr'ii Tshik. We contextualize the results of the geochemical analysis with a comparatively rich body of written and oral historical data that allows us to reconstruct the social factors involved with Mackenzie Inuit trips into the interior to procure stone. This study is the first to offer a detailed social analysis of lithic procurement practices in the Mackenzie Delta region, and it advances this type of study methodologically by using a non-destructive geochemical technique to identify the source of chert artifacts. 


\section{KUUKPAK: ARCHAEOLOGICAL AND ETHNOHISTORIC CONTEXT}

\section{The Mackenzie Inuit}

Kuukpak (NiTs-1) was the main winter village of the Kuukpangmiut, who were one of at least seven closely related Mackenzie Inuit groups that developed in the outer Mackenzie Delta and adjacent coastal regions of the western Canadian Arctic between ca. AD 1250 and 1890. The present-day descendants of these groups refer to themselves as Inuvialuit, but in keeping with established academic practice, we use the term "Mackenzie Inuit" when referring to them in a historical context. Current culture-historical frameworks for the development of Inuit culture in this region recognize three loosely defined periods: the Thule Period, the Mackenzie Inuit Period, and the Early Historic Period (Betts, 2005, 2008). The Thule Period, which spans AD 1250 to 1400, represents the initial expansion of Thule peoples into the Canadian Arctic from Alaska and the subsequent "settling in" period, during which these populations modified their adaptations to take advantage of the rich and diverse subsistence opportunities offered by the Mackenzie Delta region (Friesen and Arnold, 2008). By the time of contact with Euro-Canadian society in the early to mid-19th century, these pioneering groups had become one of the most populous Inuit societies in the Canadian Arctic, inhabiting coastal and inland areas between Franklin Bay in the east and Barter Island in the west (Usher, 1971; Betts, 2005). Oral and written historical sources indicate this society was organized into seven (perhaps eight) socioterritorial groups, a pattern which emerges in the archaeological record as early as AD 1400 and marks the beginning of the Mackenzie Inuit Period (Betts, 2005). Each socioterritorial group inhabited a fairly limited geographic region and developed a distinct (and in most cases, highly specialized) subsistence economy based on the particular resource structure of that region. A main winter village was the centre of social and economic life of a group, and each group derived its name from that of the winter village (e.g., the people of Kuukpak were called Kuukpangmiut). Betts (2005) suggests that the Mackenzie Inuit Period lasted until approximately AD 1850, when some Mackenzie Inuit groups seem to have disappeared and others restructured their subsistence economies in response to a variety of factors. Massive demographic restructuring and increased integration into the fur trade economy towards the end of the 19th century mark the end of the Early Historic Period. Betts $(2005,2008,2009)$ provides detailed analyses of the development of the diverse subsistence and settlement strategies of the various Mackenzie Inuit socioterritorial groups. In this paper, we focus primarily on the archaeological record of the Kuukpangmiut.

\section{Kuukpak and the Kuukpangmiut}

Kuukpak, located in the estuary where the East Channel of the Mackenzie River empties into Qangmaliq Bay, was the main winter village of the Kuukpangmiut during the Mackenzie Inuit Period (Fig. 1). The Prince of Wales Northern Heritage Centre carried out extensive archaeological investigations at Kuukpak in the 1980s, defining six site areas over an $800 \mathrm{~m}$ stretch of shoreline (Arnold, 1986, 1994). Most of these areas contain the remains of one or more large semi-subterranean winter houses and numerous cache pits. Deep middens associated with many of the house features indicate annual reoccupation of these structures over many years. While the remains of 21 house features are present at Kuukpak, this number does not accurately reflect the size of the village at the time of its abandonment because an unknown number of houses and associated features have been lost to shoreline erosion (Arnold, 1994). The excavated contexts at Kuukpak include four house features and a deep midden. In addition, artifacts were surface-collected from eroded contexts in all areas of the site.

Kuukpak played a central role in the subsistence adaptation of the Kuukpangmiut. Betts (2005) shows that Kuukpak and other Mackenzie Inuit winter villages are located at ecological nodes: areas characterized by a diverse array of highly productive habitats able to support multiple animal populations. In the Arctic, resource aggregations at ecological nodes are seasonally scheduled so that different resources tend to cycle through the node at different times (e.g., fish runs, waterfowl migrations, caribou migrations). Most of the Mackenzie Inuit socioterritorial groups developed specialized economies to take advantage of the particular set of resource aggregations near their winter villages. As a result, the faunal assemblages from these sites tend to be dominated by a few intensively harvested taxa (Betts, 2005, 2008). This pattern is reflected in the well-preserved faunal assemblage from Kuukpak. The Kuukpangmiut harvested a wide variety of the fish, birds, and mammals that were seasonally available in the Mackenzie Delta, but overall practiced a specialized economy focused on the exploitation of just a few taxa, including beluga whale, burbot, fishes from the subfamily Coregoninae (e.g., whitefish, ciscos, and inconnu), and muskrat (Betts, 2005, 2008). These data have important implications for understanding the land-use strategies of the Kuukpangmiut. The fact that Kuukpak was "mapped onto" an ecological node where all of these resources were available indicates that a significant part of their subsistence adaptation did not require a high degree of residential or logistical mobility (cf. Binford, 1980; Betts, 2008). Instead, resource procurement for a large part of the year probably involved short-term logistical trips within a $10 \mathrm{~km}$ radius of Kuukpak (Betts, 2008).

Kuukpangmiut land-use strategies were likely similar to those described in the ethnohistoric record for the Kitigaaryungmiut, a Mackenzie Inuit group whose main winter village was located across Qangmaliq Bay from Kuukpak (McGhee, 1974; Fig. 1). Like the Kitigaaryungmiut, the Kuukpangmiut spent mid-July to late August hunting beluga whales in the estuary at the mouth of the East Channel of the Mackenzie River. This communal hunt 
TABLE 1. Raw material frequencies for the Kuukpak chipped stone tool assemblage based on visual characteristics.

\begin{tabular}{|c|c|c|c|c|c|c|}
\hline$\underline{\text { Raw material }}$ & No. & $\%$ & No. & $\%$ & No. & $\%$ \\
\hline Thunder River chert & 187 & 49.1 & 1292 & 67.8 & 2 & 12.5 \\
\hline Quartzite & 28 & 7.3 & 44 & 2.3 & 1 & 6.3 \\
\hline Other materials & 29 & 7.6 & 68 & 3.6 & 4 & 25.0 \\
\hline Undetermined & 22 & 5.8 & 63 & 3.3 & 2 & 12.5 \\
\hline Totals & 381 & 100.0 & 1905 & 100.0 & 16 & 100.0 \\
\hline
\end{tabular}

took place in the vicinity of Kuukpak, which facilitated the storage of vast quantities of meat and blubber to support the village through the winter months. As the whaling season drew to a close, the Kuukpangmiut dispersed into the Delta to hunt and fish. The fall caribou hunt was important for the procurement of hides for winter clothing and antler for tool manufacture (Betts, 2008). In October or November, the Kuukpangmiut moved into their winter houses, subsisting primarily on stored resources until as late as January (McGhee, 1974). Towards the end of January, the Kuukpangmiut probably left their winter houses to ice fish on local rivers and lakes, and after breakup in late May or June, they spent the spring fishing and hunting throughout the Delta before congregating at Kuukpak for the summer whaling season (McGhee, 1974).

\section{The Kuukpak Chipped Stone Tool Assemblage}

The Kuukpak chipped stone assemblage consists of 381 tools (including preforms), 1905 flakes, and 16 cores. The tool assemblage contains several varieties of endscrapers, endblades, drills, and retouched and utilized flakes. The chipped stone assemblage has been sorted into raw material categories on the basis of visual characteristics (Table 1). These data indicate that a large proportion of the tools and flakes from Kuukpak were made from the raw material available at Vihtr'ii Tshik, which we refer to as Thunder River chert. Lesser amounts of grey chert (several varieties), quartzite, and other raw materials are also present in the assemblage. The geochemical analysis presented in this paper will test whether the material identified as Thunder River chert by visual examination was obtained from Vihtr'ii Tshik.

\section{VIHTR'II TSHIK}

\section{Geological Context}

Pilon (1990) provides both macroscopic and petrographic descriptions of the lithic raw material at Vihtr'ii Tshik (MiTi-1). Analysis of 11 thin sections revealed three common characteristics of the material: 1) a dark matrix containing iron oxide or hematite formations, 2) round to oval quartz/chalcedony/calcite formations, and 3) banding, with grey shale layers grading to a fine-grained black chert matrix. Microlites and pyrites are also common inclusions.
In terms of rock type, Pilon (1990) identifies the material from his thin section data as siliceous argillite. Visual identification of the material relies on the combination of a dark matrix, banding, and the presence of quartz/chalcedony/calcite inclusions.

Pokotylo (1994) provides a description of the primary geological deposits at Vihtr'ii Tshik, identifying three grades of material in the immediate vicinity of the site, including 1) light grey shaley material, 2) material containing some banding with a fine-grained black cherty matrix, and 3) material exclusively composed of a lustrous black cherty matrix. Outcrops of the grey shaley material are located on the west bank of the Thunder River, while the latter two types, which appear to exhibit the best knapping qualities, are present in the form of tabular blocks along the Mackenzie River near its confluence with the Thunder River.

Pokotylo's (1994) observations of the geological deposits correspond well with general descriptions of the bedrock geology of the Thunder River area. Bedrock geology maps indicate that the Upper Devonian Canol Formation outcrops in this area (Pilon, 1990). The Canol Formation consists of organic-rich, resistant, black siliceous cherty shale that weathers sulfur-yellow and bluish dark grey (Lemieux et al., 2007). As shown in Figure 2, Vihtr'ii Tshik is located along the Mackenzie River between Fort Good Hope and Tsiigehtchic within the northernmost exposure of the Canol Formation. According to Norris (1984), there are no known exposures of the Canol Formation along the Mackenzie River downstream of the area shown in Figure 2.

\section{Archaeological and Ethnographic Context}

Archaeological investigations at Vihtr'ii Tshik indicate that the site was used primarily as a quarry and workshop (Millar and Fedirchuk, 1975; Pilon, 1990; Pokotylo, 1994). Pokotylo (1994) undertook the most extensive survey of the site, identifying 87 lithic concentrations on a ridge along the west side of the Thunder River. The survey yielded an assemblage of 98 stone tools and more than 36000 pieces of debitage. Pokotylo's (1994) analysis of the assemblage suggests that both primary reduction of blocky pieces of raw material and tool manufacture took place at Vihtr'ii Tshik. Like many lithic quarries, Vihtr'ii Tshik has voluminous archaeological deposits that contain very few diagnostic artifacts, making it difficult to establish a chronology or culture-historical framework for the site. In this case, 


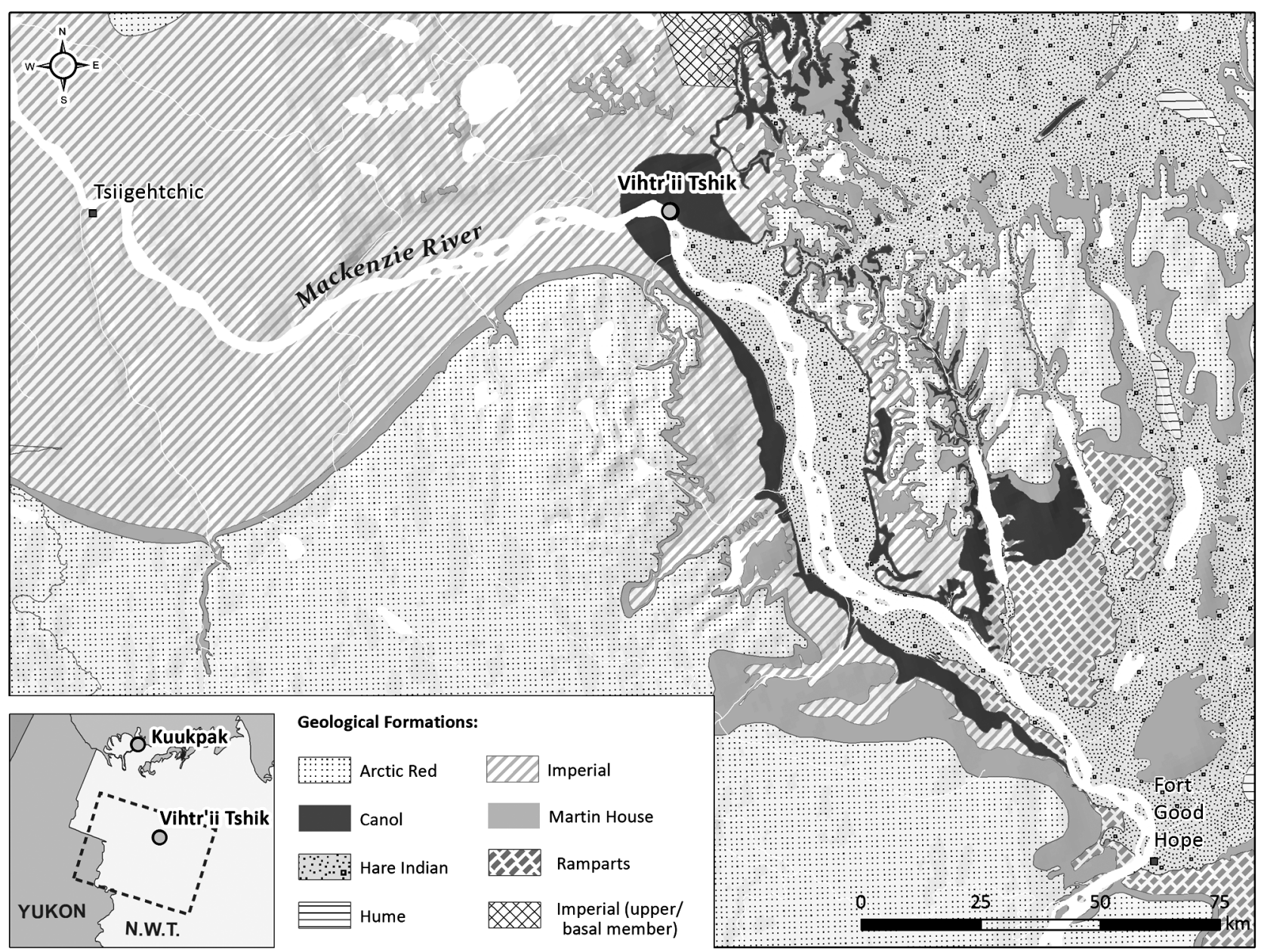

FIG. 2. Map showing the bedrock geology of the Mackenzie Valley between Fort Good Hope and Tsiigehtchic (bedrock information from Pierce and Jones, 2009).

these difficulties are exacerbated by the strong effects of a forest fire on the humic layer of the site, which led to collapsed stratigraphy and mixing of archaeological deposits (Pokotylo, 1994).

Both archaeological and oral historical data establish the regional importance of this lithic source. Pilon's (1990) analysis of thin sections of lithic artifacts from several archaeological sites in the southwest Anderson Plain indicates that this raw material was used throughout this region, and his visual comparison of raw materials in archaeological sites on a broader geographic scale provides the first indication that raw material from Vihtr'ii Tshik is present in Mackenzie Inuit sites. It is also significant that at least two Dene societies in the lower Mackenzie Valley continue to use traditional place names that identify this place as a lithic source. As noted above, Vihtr'ii Tshik is a Gwich'in word meaning 'flint at the mouth of.' As Gwichya Gwich'in elder Hyacinthe Andre relates: "You can find that [flint] only at a place called Thunder River...I know of only Thunder River and haven't heard of any other place. That's why this place is called flint creek, and you can find this up the creek" (Andre, 1992). The Slavey-speaking K'asho Got'ine of Fort Good Hope refer to the mouth of Thunder River as
Fetee Lu She, which translates as 'stone hide scraper' or 'flat skipping stones' (Hanks and Winter, 1983:49; Pilon, 1990).

\section{Written and Oral Historical References to Inuit Stone Procurement at Vihtr'ii Tshik}

As noted above, the earliest written record of Inuit use of Vihtr'ii Tshik is found in Alexander Mackenzie's journal (Lamb, 1970). While Mackenzie's journal and map do not pinpoint this location, Pilon's (1990) detailed analysis of Mackenzie's journal entries, which include accounts of his daily progress, camp locations, and a physical description of the small river, provides convincing evidence that Mackenzie is indeed referring to the Thunder River. The observations of John Richardson support this conclusion. In his narrative on the activities of the Arctic Searching Expedition on 30 July 1848, Richardson (1851:221-222) notes: "In the morning we passed an affluent thirty or forty yards wide, coming in from the eastward, which is probably the stream mentioned by Sir Alexander Mackenzie as one on whose banks Indians and Eskimos collect flint." On the evening of 29 July, Richardson's (1851:219) party 
"encamped not too far from the Old Fort," which refers to the former location of Fort Good Hope (operated by the Hudson's Bay Company from 1823 to 1827). The archaeological remains of this fort have not been identified, but historic records indicate that it was located on the left bank of the Mackenzie River, approximately opposite the mouth of the Thunder River (Castonguay, 2001). Franklin (1971) measured the latitude and longitude of Fort Good Hope in 1825. While Franklin's latitude and longitude determinations for places in the Mackenzie Valley vary in accuracy, his coordinates for the old fort place it on the right bank of the Mackenzie River just south of the Thunder River, which gives some confidence that the fort was located in the general vicinity of Thunder River. It is also significant that Richardson identified a river that flowed into the Mackenzie from the east, as the Thunder River is the only river in the area of the old fort that meets this description. Inuit use of Vihtr'ii Tshik is also recorded in the oral traditions of the Gwichya Gwich'in. As related by Heine et al. (2007:53), the Inuit "sometimes travelled up the Mackenzie as far as the mouth of Vihtr'ii Tshik to collect cooking stones and flint." Similarly, two days before Mackenzie passed Vihtr'ii Tshik on his return trip up the Mackenzie River, he stopped for several hours at a fish camp, where the inhabitantsmost likely Gwich'in - informed him that "a strong Party of the Eskmeaux comes up this River in their large Canoes in search of Flint Stones to point their Spears and Arrows" (Lamb, 1970:208).

\section{METHODS}

\section{Choosing an Analytical Technique for Geochemical Analysis}

The choice of an appropriate technique for the geochemical analysis of archaeological artifacts depends primarily on the hypothesis to be tested, but must also take into account the socio-political context in which the research is being carried out. Best practices for managing archaeological collections require heritage institutions to balance the scientific advances that could result from destructive analyses of artifacts against their mandate to preserve the integrity of the objects in their collections. If large numbers of artifacts must be tested to establish regional raw material distributions, for example, research approaches requiring destructive analyses may simply not be feasible if their impact on archaeological collections would be significant. At the same time, geochemical techniques used for archaeological fingerprinting of lithic materials should have the capacity to measure a broad range of major and trace elements and the analytical precision to yield reproducible data for establishing robust source signatures (Shackley, 2011a; Gauthier et al., 2012).

Non-destructive energy-dispersive X-ray fluorescence (ED-XRF) approaches to archaeological fingerprinting strike an effective balance between advancing science and preserving the integrity of artifacts (Lundblad et al., 2008; Mills et al., 2008, 2010; Gauthier and Burke, 2011; Shackley, 2011b; Gauthier et al., 2012; Mintmier et al., 2012). Energy-dispersive X-ray fluorescence links the ability to analyze samples with parts per million (ppm) detection limits with good analytical precision. Only minor sample preparation (i.e., cleaning) is needed, which facilitates highthroughput geochemical analysis of large sets of samples at relatively low cost. However, non-destructive analysis has a greater impact on the accuracy, precision, and limits of detection than typical destructive whole rock XRF analysis methods (wavelength dispersive-XRF with fused beads or powder pellets) because it is a surface-based technique and therefore sensitive to factors such as sample heterogeneity, grain size effects, surface irregularities (i.e., flake scars), chemical weathering, and iron oxidation states. Targeted studies are beginning to define the effects of these factors on non-destructive ED-XRF and to develop methods for minimizing their impacts on archaeological fingerprinting (e.g., Lundblad et al., 2008; Gauthier and Burke, 2011; Gauthier et al., 2012). Meanwhile, analyses of this type should be restricted to aphanitic (homogenous and finegrained) materials.

\section{Polarized Energy-Dispersive X-Ray Fluorescence}

We used non-destructive polarized energy-dispersive $\mathrm{X}$-Ray fluorescence (P-ED-XRF) to define the geochemical signatures of the raw material from Vihtr'ii Tshik and the archaeological flakes and tools from Kuukpak (cf. Gauthier and Burke, 2011). These analyses were completed at the Laboratoire de Caractérisation des Matériaux Archéologiques (LCMA) at the Université de Montréal on a PANalytical Epsilon 5 XRF instrument. This spectrometer has a three-dimensional polarizing geometry and is equipped with a $600 \mathrm{~W}$ gadolinium anode side window $\mathrm{X}$-ray tube, a $100 \mathrm{kV}$ generator, 15 polarizing and secondary targets, and a high-resolution germanium detector. It has been calibrated for the analysis of aphanitic lithic artifacts with 20 international geological certified reference materials (CRMs) containing well-established element concentrations (provided by the United States Geological Survey, Geological Survey of Japan, Institute of Geophysical and Geochemical Exploration, Canadian Certified Reference Materials Project, National Institutes of Science and Technology). Calibration curves were established for 10 major elements $\left(\mathrm{SiO}_{2}, \mathrm{TiO}_{2}, \mathrm{Al}_{2} \mathrm{O}_{3}, \mathrm{Fe}_{2} \mathrm{O}_{3} \mathrm{~T}, \mathrm{MnO}, \mathrm{MgO}\right.$, $\mathrm{CaO}, \mathrm{Na}_{2} \mathrm{O}, \mathrm{K}_{2} \mathrm{O}$, and $\mathrm{P}_{2} \mathrm{O}_{5}$ ) and 20 trace elements $(\mathrm{S}, \mathrm{Cl}$, $\mathrm{V}, \mathrm{Cr}, \mathrm{Co}, \mathrm{Ni}, \mathrm{Cu}, \mathrm{Zn}, \mathrm{As}, \mathrm{Rb}, \mathrm{Sr}, \mathrm{Y}, \mathrm{Zr}, \mathrm{Nb}, \mathrm{Ba}, \mathrm{La}, \mathrm{Ce}$, $\mathrm{Pb}, \mathrm{Th}$, and $\mathrm{U})$. Major elements were calibrated as oxides in weight $\%$ and trace elements were calibrated as metals in parts per million (ppm). Gauthier and Burke (2011) and Gauthier et al. (2012) provide further details on instrument specifications, calibration protocols, and acquisition parameters for major and trace element data using the PANalytical Epsilon 5 XRF instrument, as well as a detailed discussion of instrument accuracy, precision, and limits of detection. 


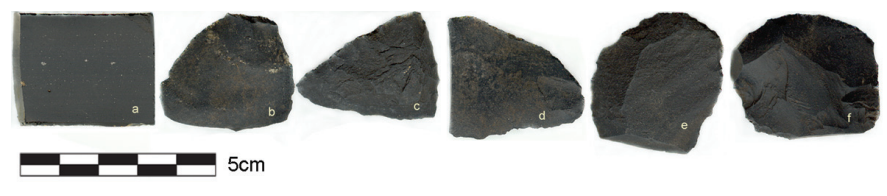

FIG. 3. Representative samples analyzed by P-ED-XRF, including a cut and polished slab from Vihtr'ii Tshik (a) and flakes and tools from Kuukpak (b-f).

X-ray fluorescence yields and analytical precision for chert are given in Gauthier et al. (2012).

\section{Sampling}

Eight blocks of raw material collected from archaeological contexts at Vihtr'ii Tshik during investigations of the site by Pilon (1990) and Pokotylo (1994) were analyzed to develop a geochemical signature for the raw material available at the quarry site. Systematic sampling of the primary geological deposits at the quarry site has not been conducted; therefore, we cannot be certain that the selected samples represent the full range of geochemical variability present in the source material. Thus our analysis rests on the assumption that the specimens found in workshop contexts at Vihtr'ii Tshik represent a reasonable geochemical cross-section of the material that precontact peoples were most likely to select from the quarry. In addition, we selected four flakes (weathered) from Vihtr'ii Tshik to compare their geochemical signatures with those of the blocks from this site.

Twenty-nine flakes and tools were selected from Kuukpak (Fig. 3). The samples were chosen from the subset of artifacts that were categorized as Thunder River chert based on visual examination of the assemblage (Table 1). The selected samples, which include formed tools $(n=5)$, retouched or utilized flakes $(n=9)$, and debitage $(n=15)$, represent all of the excavated contexts and several surface contexts at Kuukpak.

\section{Sample Preparation}

Quarry samples from Vihtr'ii Tshik (Fig. 3a) were 1) cut with a diamond saw into small rectangular slabs $(50 \mathrm{~mm} \times$ $35 \mathrm{~mm} \times 20 \mathrm{~mm} ; \mathrm{W} \times \mathrm{D} \times \mathrm{H}$ ) to permit their insertion in the Epsilon 5 sample cups, 2) polished with a silicon carbide slurry to remove saw marks and create a flat surface for analysis, and 3) cleaned with warm alcohol using an ultrasonic bath. Creating a flat, polished (i.e., unweathered) surface for analysis of the quarry samples attenuates some of the factors, such as chemical weathering and surface irregularities, that can affect surface-dependent geochemical techniques and thus facilitates the development of an accurate geochemical signature that can be used as a benchmark throughout the study.

Nine slabs were produced from the eight quarry specimens: one slab was left unpolished (MiTi-1.52), three slabs were cut and then polished on both sides (MiTi.1-58, $-892,-4357)$, two slabs were cut from the same specimen
(MiTi-1.6149) and polished on one side, and finally three slabs were cut and polished on one side (MiTi-1.5542, -8549, -11009). This procedure permitted the analysis of 12 different surfaces by P-ED-XRF for the source material. One analysis per flake was performed for the four flakes from Vihtr'ii Tshik and for the 29 flakes and tools from Kuukpak. Like the quarry slabs, tools and flakes from Kuukpak and Vihtr'ii Tshik were cleaned in warm alcohol in an ultrasonic bath prior to analysis.

\section{Choosing Robust Elements}

Following the guidelines published in Gauthier et al. (2012), a refined geochemical data set was produced by filtering out elements that did not meet certain analytical and geochemical criteria. Nine of the 30 elements that were calibrated are used here to determine a more robust geochemical signature for the quarry and archaeological samples: $\mathrm{SiO}_{2}, \mathrm{Fe}_{2} \mathrm{O}_{3} \mathrm{~T}, \mathrm{~K}_{2} \mathrm{O}, \mathrm{Rb}, \mathrm{Sr}, \mathrm{Y}, \mathrm{Zr}, \mathrm{Ba}$, and $\mathrm{Ce}$. These elements show a relative standard deviation of less than $5 \%$ (based on 10 repeat analyses of a quarry sample), good count rates (XRF yield) or a very high concentration in chert $\left(\mathrm{SiO}_{2}\right)$, and relatively low intra-quarry site variations. Gauthier et al. (2012) provide a more detailed discussion of analytical and geochemical criteria for choosing robust elements.

\section{Diagrams and Statistical Analyses}

Descriptive statistics (boxplots), normalized spider diagrams, and principal components analysis (PCA) are used to portray the geochemical signatures of the Vihtr'ii Tshik quarry samples and compare them to those of the flakes and tools from Kuukpak.

Spider diagrams use selected major and trace element concentrations normalized to upper continental crust values to create geochemical patterns that can be used to compare the geochemical signatures of quarry samples and archaeological artifacts graphically. The normalization values for the upper continental crust are taken from Taylor and McLennan (1985) and McLennan (2001). The elements used are presented in order of increasing ionic potential.

Principal components analysis (PCA) is a variable reduction procedure that is often used in archaeological sourcing studies to facilitate the interpretation of geochemical data by transforming a complex set of original variables (large in number and often correlated) to a smaller number of uncorrelated variables (principal components) that account for most of the variance in the original dataset (Speakman et al., 2008). Principal components analysis results and graphs were produced using the Missouri University Research Reactor murrap.gcg program (version 8.3 running with the Gauss run-time module) developed by Dr. Danielle $\mathrm{K}$. Hauck at the Archaeometry Laboratory and modified for publication using illustration software. The PCA was performed on a variance-covariance matrix based on base-10 logarithms of the element concentrations determined for the quarry samples. 

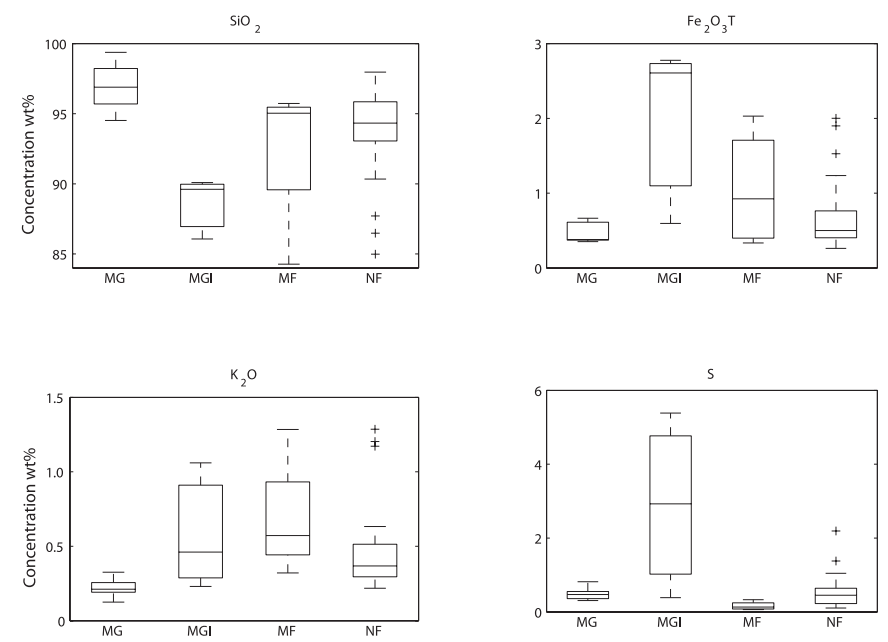

FIG. 4. Boxplots for three selected major elements and sulfur for the Vihtr'ii Tshik (MiTi-1) and Kuukpak (NiTs-1) materials analyzed in this study. MG $=$ MiTi-1 geological (6 slabs, 9 analyses), MGI $=$ MiTi-1 geological impure (3 slabs, 3 analyses), MF = MiTi-1 flakes (4 flakes, 4 analyses), NF $=$ NiTs-1 flakes ( 29 flakes, 29 analyses), $+=$ outlier (defined as more than 1.5 times the interquartile range).

\section{RESULTS}

\section{Chemical Make-Up of Quarry and Artifact Materials}

The chemical data for the quarry samples indicate that three of the nine quarry samples from Vihtr'ii Tshik are outliers for several major and trace elements; therefore, these three will be kept separate on the following figures (MGI = MiTi-1 geological impure). A macroscopic examination of all the slabs confirms mineralogical heterogeneity visible on the millimetre and centimetre scale: variable scale banding showing variable grain sizes and random sulfide-rich laminations and pods. It is also expected that some geochemical variability in the source material will be directly related to stratigraphic heterogeneity in the geological deposits exposed at the quarry site. Systematic sampling of the bedrock outcrops at the quarry source is needed to fully characterize the geochemical variability of the raw material.

Figure 4 shows boxplots for the three selected major elements $\left(\mathrm{SiO}_{2}, \mathrm{Fe}_{2} \mathrm{O}_{3} \mathrm{~T}\right.$, and $\left.\mathrm{K}_{2} \mathrm{O}\right)$ and sulfur for all the slabs and flakes analyzed in this study. The sample groups presented here are the following: $\mathrm{MG}=\mathrm{MiTi}-1$ geological (six slabs, nine analyses); MGI = MiTi-1 geological samples identified as "impure" because of their outlier status (three slabs, three analyses); MF = MiTi-1 flakes (four flakes, four analyses); and NF = NiTs-1 flakes (29 flakes, 29 analyses). Except for MGI, it is clear that the quarry materials and artifacts are highly siliceous $\left(>90 \% \mathrm{SiO}_{2}\right)$. Iron $\left(\mathrm{Fe}_{2} \mathrm{O}_{3} \mathrm{~T}\right)$ and sulfur (S) are greater in two of the three MGI samples, which directly reflects sulfide-rich laminations and pods (potentially pyrite). Sulfur is presented to show that it should be considered as a major element $(>1 \%)$ and that it is highly concentrated for MGI. It is not part of the robust
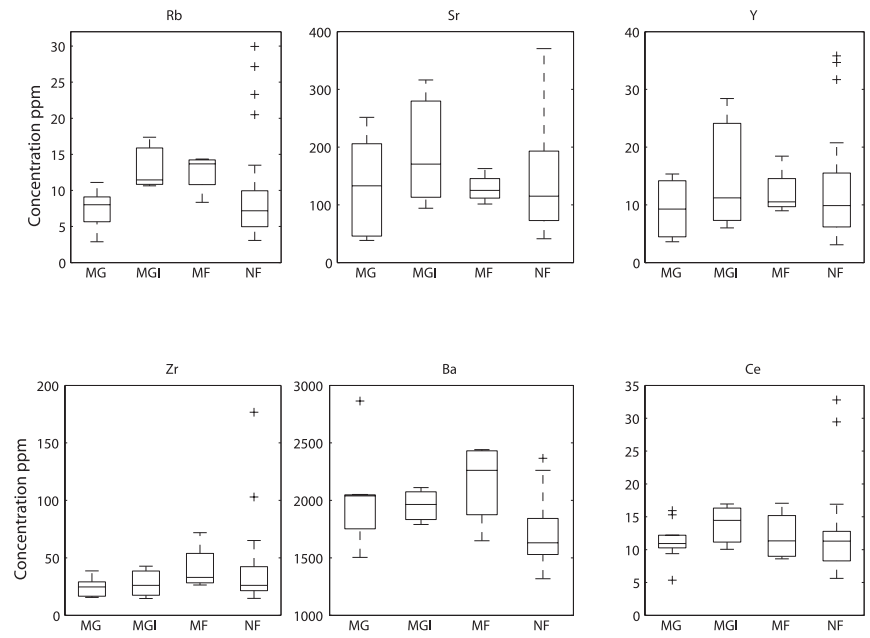

FIG. 5. Boxplots for six selected trace elements for the Vihtr'ii Tshik (MiTi1) and Kuukpak (NiTs-1) materials analyzed in this study. MG = MiTi-1 geological (6 slabs, 9 analyses), MGI = MiTi-1 geological impure (3 slabs, 3 analyses), MF = MiTi-1 flakes (4 flakes, 4 analyses), NF $=$ NiTs-1 flakes (29 flakes, 29 analyses), $+=$ outlier (defined as more than 1.5 times the interquartile range).

element list (due to low XRF yield, poor calibration, sulfide nugget effect, etc.) and will not be used further.

Figure 5 shows boxplots for $\mathrm{Rb}, \mathrm{Sr}, \mathrm{Y}, \mathrm{Zr}, \mathrm{Ba}$, and $\mathrm{Ce}$ for all the slabs and flakes analyzed in this study. The materials analyzed here show very enriched concentrations of strontium and barium when compared to other siliceous sediments analyzed at LCMA. It is also important to note that the quarry materials contain variable but non-negligible amounts of Ni, Zn, and U (not shown). The NiTs-1 artifacts exhibit the same unusual chemical attributes as the MiTi-1 materials when compared to the LCMA siliceous lithic materials database.

The Kuukpak flakes show up to four outlier samples (defined as more than 1.5 times the interquartile range; shown by + symbol on Figs. 4 and 5) for seven of the nine robust elements. The samples that are primarily responsible for this behavior are NiTs-1.154e (4 elements), NiTs-1.980b (4 elements), NiTS-1.2536 (3 elements), NiTs-1.2721a (7 elements). This result could be due to weathering or could suggest that the outlier samples derive from a different source altogether. This question will be addressed below in the Geochemical Effects of Weathering section.

\section{Quarry Signature and Rock Type}

A normalized spider diagram using nine elements is used to portray the geochemical signature of the quarry samples (Fig. 6). High concentrations of $\mathrm{Si}$, Ba, and $\mathrm{S}$ (not shown; see Fig. 4) define the quarry samples; the remaining elements are all depleted by comparison to upper continental crust values. The quarry materials are not homogeneous, as shown by the pattern range (thickness), but this heterogeneity is not uncharacteristic for siliceous sediments on the outcrop scale (see Gauthier et al., 2012). Considering the 


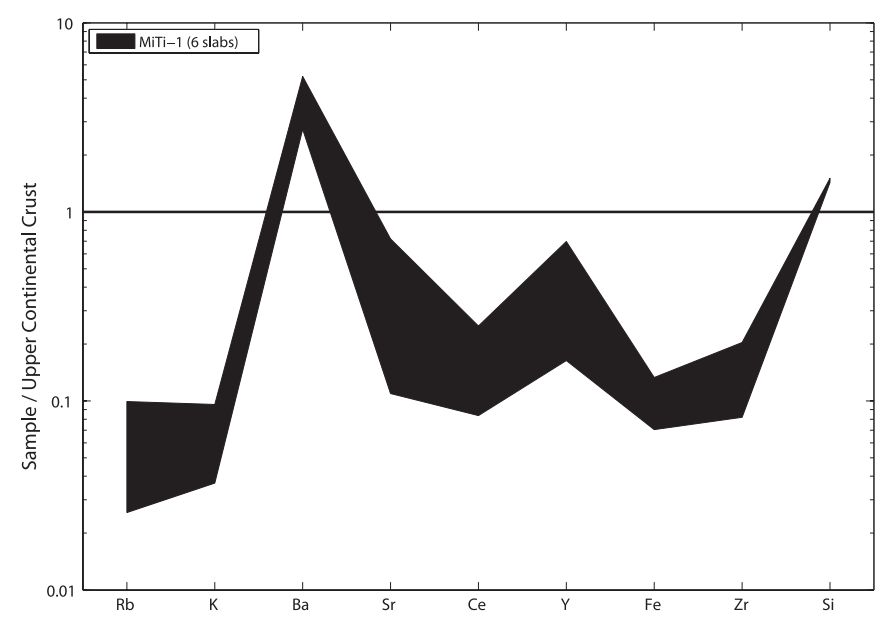

FIG. 6. Upper continental crust normalized spider diagram for the selected Vihtr'ii Tshik (MiTi-1) quarry samples (6 slabs, 9 analyses) showing enrichment for $\mathrm{Ba}$ and $\mathrm{Si}$ and depletion for all others.

geological sedimentary context (Canol Formation), the high $\mathrm{SiO}_{2}(>94 \mathrm{wt} \%)$ and low $\mathrm{Al}_{2} \mathrm{O}_{3}(<2 \mathrm{wt} \%$, not shown) contents, and their depleted upper continental crust patterns, we strongly recommend that these rocks be referred to as chert, notwithstanding the fact that no international chemical classifications exist for siliceous sediments. Pilon (1990) classifies these materials on the basis of a petrographic analysis as shale with high silicate content or siliceous argillite, or both. Shales and argillite show very high aluminum relative to chert, and their upper continental crust normalized patterns are flat and do not diverge much from unity. Our quarry samples are not compatible with these chemical characteristics. We propose that this material be referred to as Thunder River chert.

\section{Geochemical Fingerprinting of Archaeological Flakes and Tools}

As published geochemical variation diagrams do not exist specifically for chert, a spider diagram and a principal components analysis (PCA) factor plot for the nine selected elements are used to compare the Vihtr'ii Tshik (MiTi-1) and Kuukpak (NiTs-1) flakes to the Vihtr'ii Tshik quarry material and establish memberships.

Figure 7 shows the geochemical patterns for the Vihtr'ii Tshik quarry material and Kuukpak flakes (excluding the four outliers identified above). Although the Kuukpak flakes generally show a greater range in normalized values (pattern thickness), it is quite clear that they have strong chemical affinities with the Vihtr'ii Tshik quarry material.

To statistically ascertain this chemical relationship (nongraphical method), a PCA was performed exclusively for the MG samples ( $\mathrm{n}=9$ analyses) using the nine selected chemical elements in order to define a quarry ellipse $(90 \%$ confidence interval) on a PC1 vs. PC2 component scores graph (Fig. 8). The results of the PCA indicate that $91.9 \%$ of the variance in this dataset is explained by the first two principal components, and the element vectors (not shown)

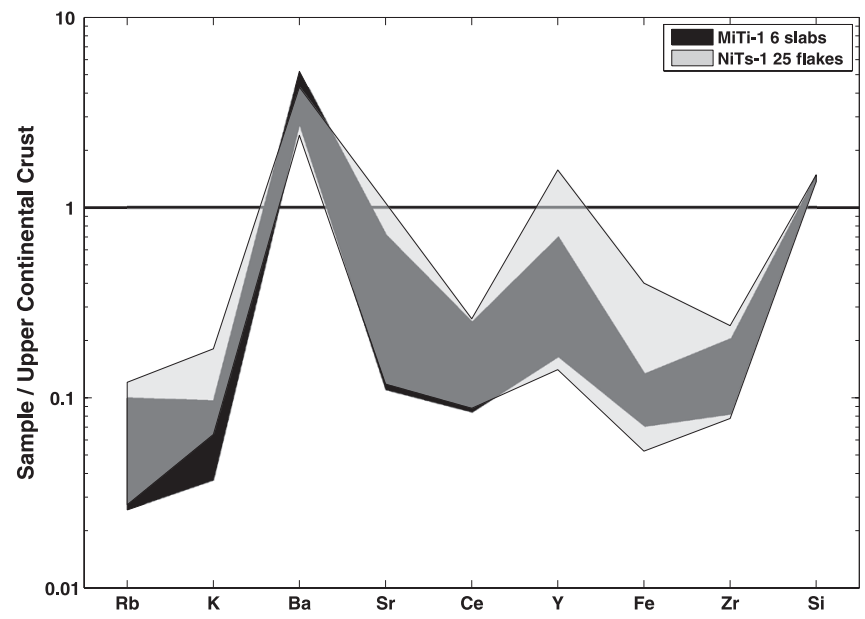

FIG. 7. Upper continental crust normalized spider diagram comparing the Vihtr'ii Tshik (MiTi-1) quarry samples (6 slabs, 9 analyses) with the nonoutlier Kuukpak (NiTs-1) flakes and tools (25 flakes, 25 analyses).

indicate high loadings for $\mathrm{Sr}$ and $\mathrm{Y}$ on $\mathrm{PC} 1$ and $\mathrm{Rb}$ and $\mathrm{K}_{2} \mathrm{O}$ on PC2. While there are no hard guidelines for minimum sample size for PCA, we acknowledge that the low sample size $(n=9)$ and low sample-to-variable ratio (1:1) used to construct the MG ellipse increase the risk of unreliable results, and thus the PCA should be considered exploratory rather than definitive. Nonetheless, considering the highly unique geochemical signature of Thunder River chert (atypical for chert), we found PCA a useful and unbiased tool for comparing the chemistry of the artifacts in question with the quarry samples and assisting in the identification of outliers. To compare the MGI, MG, and NF samples to the quarry ellipse, the transformation matrix generated for the PCA of the MG samples was used to compute and project component scores for MGI, MF, and NF samples onto the $\mathrm{PC} 1$ vs. PC2 graph (Fig. 8). Figure 8 shows the following:

1. Twenty-five of the 29 (86\%) Kuukpak flakes plot within the MG ellipse, confirming their strong chemical relationship with the quarry material.

2. Four Kuukpak flakes act as outliers, paralleling their behavior on boxplots (NiTs-1.154e, -980b, -2536, -2721a).

3. One MGI sample (MiTi-1.11009) plots inside the MG ellipse, while the other two act as outliers (MiTi-1.52 and -5542).

4. Two of the four Vihtr'ii Tshik flakes plot inside the ellipse, one plots very close, and one is an obvious outlier (MiTi-1.0040).

The spider diagram and PCA indicate that the Kuukpak flakes and tools were likely sourced from Vihtr'ii Tshik. The dark colour, the high $\mathrm{Ba}$ and $\mathrm{S}$ concentrations, and the non-negligible concentrations of $\mathrm{Ni}, \mathrm{Zn}$, and $\mathrm{U}$ in this chert material are unique among the chert samples analyzed at the LCMA laboratory by the same XRF method (e.g., West Athens Hill and Onondaga, NY; Munsungun, ME; Hathaway, VT; and La Martre and Touladi, PQ). Although some 


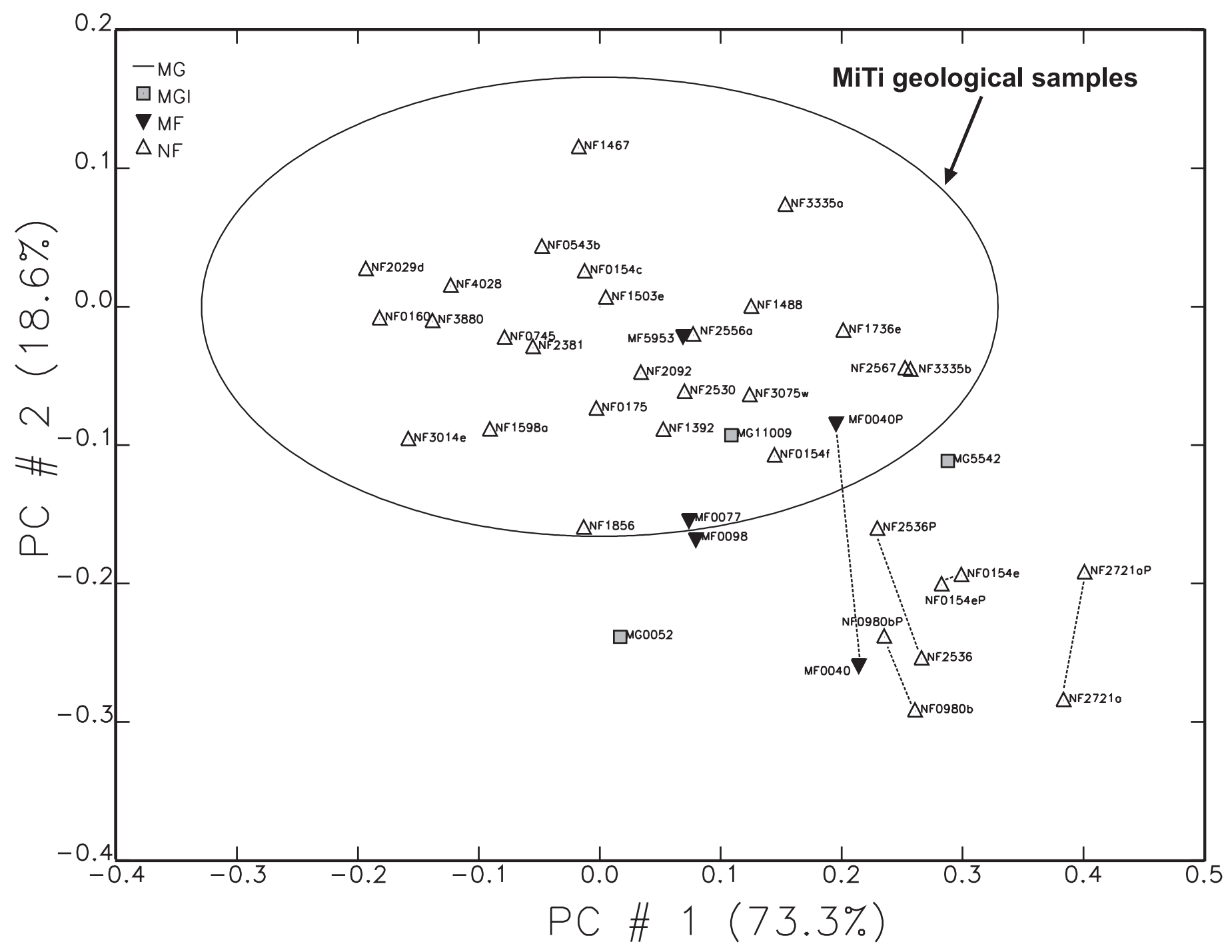

FIG. 8. PCA component score diagram for the Vihtr'ii Tshik (MiTi-1) and Kuukpak (NiTs-1) materials analyzed in this study. MG $=$ MiTi-1 geological (6 slabs, 9 analyses), MGI $=$ MiTi-1 geological impure ( 3 slabs, 3 analyses), MF $=$ MiTi-1 flakes ( 4 flakes, 4 analyses), NF = NiTs-1 flakes ( 29 flakes, 29 analyses). The tie lines link the component scores obtained before and after removal of the weathering rind. The letter $\mathrm{P}$ added to the end of the artifact number indicates that it was polished.

samples are outliers, they still show the main characteristics found for the Vihtr'ii Tshik material, and their outlier position may be the result of stratigraphic heterogeneity at the quarry site.

\section{Geochemical Effects of Weathering}

The weathering rinds that form on lithic artifacts through their interaction with atmospheric or subterranean media (or both) can seriously affect the geochemical composition of the surfaces of artifacts. It is important to consider this factor when using surface-based geochemical fingerprinting techniques such as non-destructive XRF (Gauthier and Burke, 2011; Gauthier et al., 2012). The responses of different elements to weathering processes can vary greatly, and are dependent on such factors as the role of an element in the chemical structure of a particular type of rock, the physico-chemical conditions (e.g., $\mathrm{pH}$, bacterial activity, water content) of the substrate in which an artifact was buried, and the length of time an artifact was buried. Thus it is important to evaluate and establish which elements in a raw material tend to be affected by weathering processes (mobile elements) and which do not (immobile elements) in a given depositional context before using them as a reference.

As four Kuukpak flakes and one Vihtr'ii Tshik flake were acting as outliers for many elements and we could not precisely ascribe this behavior to weathering or to source characteristics, we opted to remove the weathering rind and reanalyze a fresh surface of these flakes (Fig. 9). We obtained permission from the Prince of Wales Northern Heritage Centre and the Canadian Museum of Civilization to mechanically remove the weathering rinds by manually grinding them down using a silicon carbide slurry. Reanalysis of the ground flakes facilitates a direct comparison of element concentrations before and after removal of 


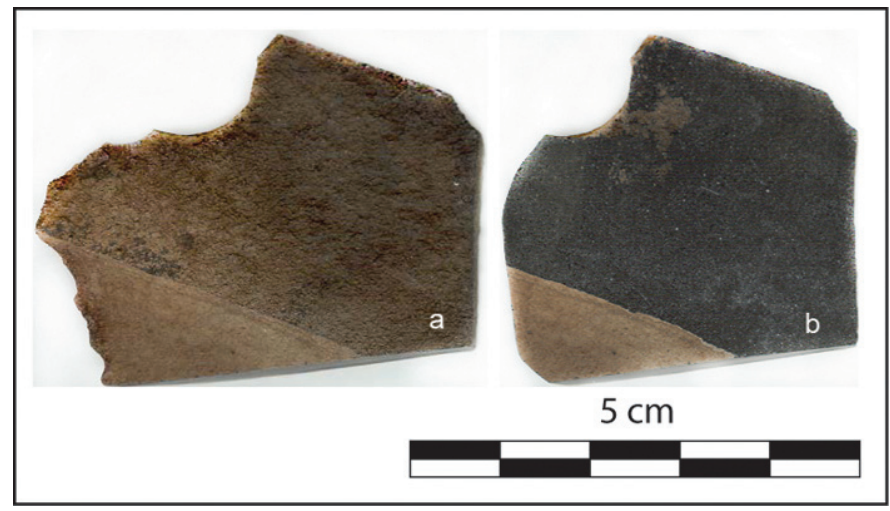

FIG. 9. Flake from Vihtr'ii Tshik (MiTi-1:0040) (a) before and (b) after removal of its weathered surface.

the weathering rind. Figure 8 shows the effect of removing weathering products on PCA component scores. The before and after component scores are linked by dotted tie lines. These data show that the outlier status of the weathered flake from Vihtr'ii Tshik (MiTi-1.0040) was largely resolved by removal of its weathered surface, as the component score of the unweathered surface now plots well within the MG ellipse. In contrast, while it is clear that some element concentrations in the samples from Kuukpak were affected by chemical weathering (displacement on PCA graph), all four outlier samples from this site maintained their outlier status. This indicates that these four flakes truly reflect geochemical variability in the source material not captured in the MG quarry samples analyzed in this study, or that they derive from a different source altogether.

\section{DISCUSSION}

\section{Raw Material Use at Kunkpak}

What do the geochemical data tell us about how important Thunder River chert was to the Kuukpangmiut? While Table 1 suggests that Thunder River chert is by far the most abundant material in the tool (49.1\%) and flake (67.8\%) assemblages, these data must be viewed with some caution. The 29 flakes and tools from Kuukpak analyzed in this study represent only a $2 \%$ sample of the approximately 1500 flakes and tools identified as Thunder River chert by visual examination. In addition, black, fine-grained, conchoidal rocks are common in archaeological contexts in the Mackenzie Valley, and qualitative visual comparison of rock types is susceptible to observer error (cf. Calogero, 1992). Most importantly, the geochemical analysis leaves open the possibility that four of the 29 samples from Kuukpak could derive from a separate source. Still, the fact that $86 \%$ of the samples analyzed can be sourced to Vihtr'ii Tshik suggests that Thunder River chert is relatively abundant in the Kuukpak assemblage. As a rough estimate, $86 \%$ of the 1481 tools, flakes, and cores identified as Thunder River chert on the basis of visual characteristics is equivalent to roughly 1274
(55\%) of the 2302 artifacts in the Kuukpak chipped stone assemblage. Technological data from the debitage assemblage provide supporting evidence for the relative abundance of Thunder River chert in the assemblage. Numerous flakes identified as Thunder River chert by visual examination contain remnants of angular joint surfaces, indicating that they were struck from tabular blocks derived from a primary source, which is consistent with the form in which Thunder River chert is found at Vihtr'ii Tshik.

\section{The Social Context of Kuukpangmiut Lithic Procurement in the Lower Mackenzie Valley}

If the Kuukpangmiut obtained more than half of their lithic raw material from Vihtr'ii Tshik, as these results suggest, how did they procure an adequate supply of this material, and what role did social factors play in shaping their procurement logistics? While it is often difficult to determine the exact mechanisms of lithic raw material procurement from archaeological data (see discussions in Meltzer, 1989; Ellis, 2011), the oral and written historical sources related to Inuit stone procurement in the lower Mackenzie Valley presented above suggest that the Kuukpangmiut obtained stone from Vihtr'ii Tshik through direct procurement. In other words, the Kuukpangmiut made special trips to Vihtr'ii Tshik to collect stone rather than obtaining it through embedded procurement, in which stone is collected in the context of trips made for other purposes - primarily subsistence pursuits (Binford, 1979; Bamforth, 2006). The information provided by both the Gwichya Gwich'in and Alexander Mackenzie suggests that Inuit trips upriver were specific to stone procurement. Direct rather than embedded procurement of Thunder River chert is also consistent with archaeological and ethnohistorical data related to the Kuukpangmiut subsistence adaptation, which involved the intensive procurement of subsistence resources in the vicinity of Kuukpak. The Kuukpangmiut did travel into the Mackenzie Delta in the warm season to hunt and fish. The fall caribou hunt was particularly important, but it is unlikely that the Kuukpangmiut had to travel too far upriver to intercept caribou, as the present-day ranges of boreal forest caribou and both the Cape Bathurst and Bluenose East migratory tundra caribou herds overlap with the eastern Mackenzie Delta (Hummel and Ray, 2008). While it is possible that procurement of Thunder River chert coincided with trips upriver to trade with the Dene, it is unclear whether these trading events were common in the pre-fur trade era.

Trade with other groups is another possible mechanism for the procurement of Thunder River chert by the Kuukpangmiut. It is possible, for example, that the Kuukpangmiut obtained Thunder River chert through trade with another Mackenzie Inuit group that collected this material from the quarry through direct procurement, such as the Kitigaaryungmiut, whose winter village was located across Qangmaliq Bay from Kuukpak. Alternatively, the Kuukpangmiut may have obtained Thunder River chert through trade with the Dene. Gwichya Gwich'in oral 
tradition indicates that Dene hunters traveled as far north as the Caribou Hills to hunt caribou in the summer, and that the Gwichya Gwich'in and Mackenzie Inuit gathered near Tsiigehtchic to trade (Heine et al., 2007; Fig. 1). Yet, given that Thunder River chert is likely the most abundant raw material in the Kuukpak chipped stone assemblage, it is unlikely that they would have depended solely on trade to procure such a critical resource, especially in a social landscape in which the potential for hostilities between groups was high.

Kuukpangmiut groups traveling up the Mackenzie River to Vihtr'ii Tshik went deep into lands inhabited by Dene hunter-gatherer societies, including the Gwichya Gwich'in and the K'asho Got'ine. While it is difficult to define precise traditional territories for late precontact populations in the lower Mackenzie Valley, it is likely that the Mackenzie Inuit crossed into the lands of the Gwichya Gwich'in in the vicinity of Point Separation (Heine et al., 2007:49; Fig. 1), and traveled as far as the approximate border (along the Mackenzie River) between the Gwichya Gwich'in and K'asho Got'ine, which the oral traditions of both groups indicate was marked by the Thunder River (Hanks and Winters, 1983; Heine et al., 2007). Not surprisingly, the oral traditions of both the Gwichya Gwich'in and K'asho Got'ine record detailed information related to the use of Vihtr'ii Tshik by the Mackenzie Inuit. A Gwichya Gwich'in story related by Heine et al. (2007:53) notes that the Inuit:

[S]ometimes travelled up the Mackenzie as far as the mouth of Vihtr'ii Tshik to collect cooking stones and flint. In the old days this could be a dangerous journey, because nobody was quite sure whether the next encounter between these travelers and the Gwichya Gwich'in would be friendly or lead to a fight. It was for the same reason that the Eskimo would not travel up Tsiigehnjik [Arctic Red River]. The river was too narrow to avoid arrows shot at their boats during a surprise attack from the riverbank.

In contrast, information related by K'asho Got'ine elder Jerry Lennie indicates that:

[T] he quarry was so important to survival of the people in the broad region that there was a treaty between the Inuit, Gwich'in and K'asho Got'ine that made the quarry a "safe" zone. Before this treaty, they used to kill each other whenever there was an encounter.

(I. Kritsch, pers. comm. 2012).

It is interesting to compare this information with observations recorded by Alexander Mackenzie when he visited the fish camp noted above on 22 July 1789:

During the 2 Hours that I remained here I kept the English Chief continually questioning them - the result of which is as follows That their Nation or Tribe is very numerous, that the Eskmeaux are always at variance with them, that they kill their Relations when they find them weak. Notwithstanding, they promise to be always Friends, they of late have shewn their Treachery by Butchering some of their People in proof of which some of the Relations of those deceased shewed use that they had cut off their Hair upon the occasion, \& that they are determined not to believe the Eskmeaux any more; that they will collect their Friends to go to revenge the Death of their Friends (Lamb, 1970:208).

Taken together, these quotes suggest Dene-Mackenzie Inuit relations cannot easily be characterized as friendly or unfriendly. Indeed, while Gwichya Gwich'in oral tradition contains numerous stories of hostile encounters with the Mackenzie Inuit, it also suggests that these groups sometimes gathered near Tsiigehtchic in the summers to trade (Heine et al., 2007).

While these historical references are perhaps one-sided, in that they do not reflect the voices of the Mackenzie Inuit, they suggest that although pre-fur trade relations between the Mackenzie Inuit and the Dene of the lower Mackenzie Valley were amicable at times, the potential for hostilities was ever-present. Historical accounts suggest that this situation continued and perhaps intensified during the early fur trade era, with the Gwich'in establishing a strong "middleman" position between the Mackenzie Inuit and fur trade posts farther up the Mackenzie River (see Slobodin, 1960).

Later historical references to Inuit traveling up the Mackenzie River to collect flint further illuminate the social context of these trips. In his report of the Stefánsson-Anderson Arctic Expedition, Vilhjálmur Stefánsson (1919:13), who lived and traveled with the Mackenzie Inuit in 1906-07, notes that the memories of both the Inuit and the Indians establish that the former traveled up the Mackenzie River to obtain "stone for knives and missile points." He further remarks:

[W]e have definite accounts of organized expeditions into the country of the Good Hope Indians [K'asho Got'ine], not real war expeditions it is true, but still expeditions made in force with a show of arms and with no secrecy. The Indians of Good Hope tell that the Eskimo used to come in singing and shouting boatloads. They do not appear to have made incursions into the forest in search of Indians to kill or to plunder. On the other hand, they were so confident in their numbers and strength that they evidently feared no attack.

While Stefánsson's report does not provide detailed information on the source(s) of this information, it is clear from a more popular account of his Arctic expeditions (Stefánsson, 1922) that he obtained this knowledge from Roderick MacFarlane, whom he met in Winnipeg before traveling north to the Mackenzie Delta. MacFarlane was the Clerk in charge of Fort Good Hope from 1854 to 1861 , at which time the fort was already at its present location. An important contrast between Stefánsson's account and 
the historical evidence presented above is that it identifies the Ramparts, located just upstream of the present site of Fort Good Hope, as the stone source sought by the Inuit. John Richardson (1851) makes a similar observation in his report of the Arctic Searching Expedition. At present, there is no archaeological evidence to indicate the presence of a lithic source in the vicinity of the Ramparts. It may be the case that the stories heard by MacFarlane and Richardson referred to the previous location of Fort Good Hope opposite the Thunder River, but it also remains a possibility that the Mackenzie Inuit ventured as far upriver as the Ramparts to procure stone.

The information recorded by Stefánsson is consistent with Alexander Mackenzie's observation that a strong party of Inuit traveled upriver to procure stone. While the presence of the Gwichya Gwich'in and K'asho Got'ine in the lower Mackenzie Valley did not block the Kuukpangmiut's access to Vihtr'ii Tshik, it did require them to invest significant resources in the formation of special task groups prepared to traverse a social landscape in which hostilities could erupt between themselves and other groups. In this manner, social factors clearly shaped the lithic raw material procurement logistics of the Kuukpangmiut.

The historical record illuminates how the Kuukpangmiut collected Thunder River chert but offers little insight into why they traveled so far to procure stone for chipped stone tool manufacture. While an $800 \mathrm{~km}$ round trip seems extreme for hunter-gatherer lithic raw material procurement, especially for a relatively sedentary society, it is important to note that direct procurement of Thunder River chert was probably facilitated by two factors. Kuukpak and Vihtr'ii Tshik are linked by a water route, which allowed the Kuukpangmiut to access the quarry by boat, and the heavy transport capacity of Inuit umiaks-Alexander Mackenzie refers to umiaks as "their large canoes"-probably enabled bulk procurement of lithic raw material (cf. Blair, 2010). Still, the long-distance procurement of Thunder River chert requires further explanation.

Unfortunately, very little is known about the lithic landscape of the Mackenzie Inuit area. McGhee (1974) notes that the blue-grey chert present in the Kitigaaryuk assemblage was likely obtained from local river cobbles. The presence of cortex-covered grey chert nodule fragments in the Kuukpak debitage assemblage provides some support for this hypothesis, but there is little data available on how abundant this material is in local contexts. Toews (1998:112) offers preliminary observations on the distribution of grey quartzite, or "quartz arenite," in archaeological sites on Banks Island and in the Mackenzie Delta region, but again there is little information available on sources except for a few indications that this material is widespread in local tills in parts of the region. Clark (1975) documents outcrops of a fused rock on the east bank of the lower Anderson River, and notes that this material was utilized locally for stone tools.

The best-characterized lithic source in the Mackenzie Delta region consists of several areas on the Cape Bathurst Peninsula where "clinker" is formed by the spontaneous combustion of organic-rich shales (Le Blanc, 1991). This material, resembling coarse vesicular basalt to grainy obsidian, is the predominant lithic material found in archaeological sites on the Cape Bathurst Peninsula, and its regional distribution includes archaeological sites on the Tuktoyaktuk Peninsula, southwest Banks Island, and the southwest Anderson Plain. The thermally fused shale is formed in features called bocannes, which are present along the coast of Franklin Bay in the Smoking Hills and along both the modern and old channels of the Horton River (Le Blanc, 1991). In contrast to most quarries associated with bedrock exposures, bocannes and the clinker they create tend to appear and disappear fairly rapidly. Existing bocannes are eroded away or covered in colluvial material even as new ones are being formed. Thus, while Le Blanc (1991) recorded several bocannes where flakeable clinker was available, none of these show signs of quarrying activity because they probably post-date precontact occupations in the region. In this way, the locations of clinker sources in the exposures of the Smoking Hills Formation on the Cape Bathurst Peninsula were dynamic compared to other lithic sources.

In contrast to Thunder River chert, clinker from the Cape Bathurst Peninsula is present in the Kuukpak chipped stone tool assemblage at a very low frequency (ca. 1.2\%). It is interesting to note that the distance by water from Kuukpak to areas of active clinker formation on the shore of Franklin Bay is shorter than the river distance between Kuukpak and Vihtr'ii Tshik, yet the Kuukpangmiut did not target this source for direct procurement (Fig. 10). Several factors could account for this apparent discrepancy. The dynamic nature of clinker sources may have made their locations less predictable than exposures of Thunder River chert at Vihtr'ii Tshik, or Thunder River chert may have been a more effective material for the tasks for which the Kuukpangmiut used chipped stone tools. Indeed, Thunder River chert may have been ideal as a material that could be initially shaped by flaking and then ground - an important aspect of Thule lithic technology. Travel by boat along the Arctic Coast to the Cape Bathurst Peninsula may have been physically more dangerous than travel up the Mackenzie River, although given their Thule cultural roots, it is probably reasonable to assume that the Kuukpangmiut were expert seafarers. Alternatively, the fact that the Kuukpangmiut subsistence adaptation was oriented to the East Channel of the Mackenzie River and to some extent the inner Mackenzie Delta may have favoured travel upriver to Vihtr'ii Tshik from warm season hunting and fishing camps in the inner delta. Another distinct possibility, however, is that the social landscape of the Mackenzie Inuit created a social barrier to Kuukpangmiut access to clinker.

Betts (2008) notes that the Mackenzie Inuit groups were highly territorial and apprehensive about crossing territorial borders. The system of territoriality in this region may account in part for the key characteristics of the Mackenzie Inuit socioeconomic system. As Betts (2005:60) notes, "in environments like the Mackenzie Delta region, economies associated with a territorial system may be associated 


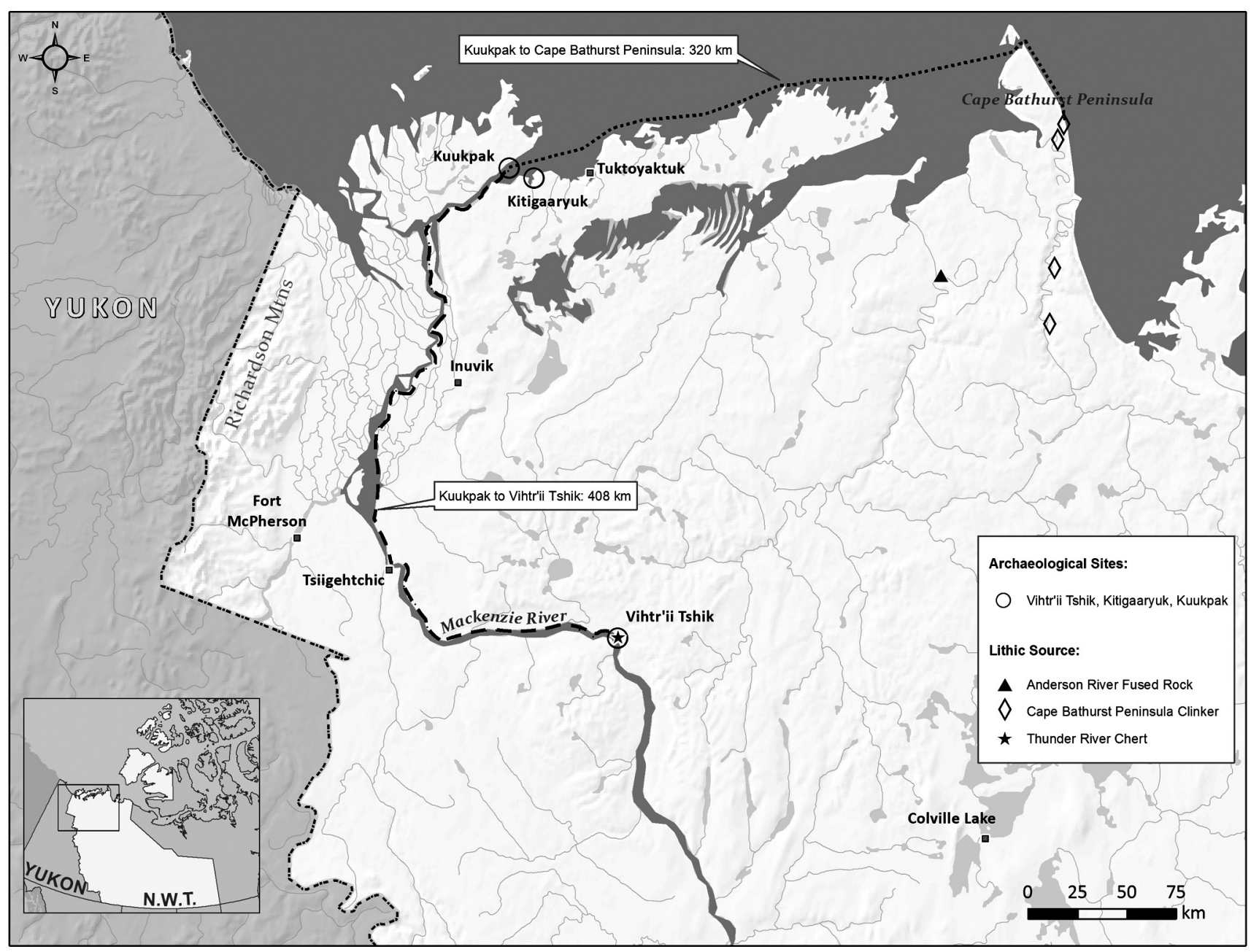

FIG. 10. Map comparing possible water routes between Kuukpak and Vihtr'ii Tshik and Kuukpak and clinker sources on the Cape Bathurst Peninsula.

with a diversity of specialized strategies, with each territorial group focused on key resources available at different locations within a region." The hypothetical water route between Kuukpak and the Cape Bathurst Peninsula shown in Figure 10 would require the Kuukpangmiut to traverse the territories of at least three other Mackenzie Inuit groups. In this manner, while the geographic distance between Kuukpak and sources of clinker may have been shorter than the distance between Kuukpak and Vihtr'ii Tshik, the social distance (cf. Walsh, 1998) may have been much greater. Rather than by direct procurement, small amounts of clinker may have filtered into Kuukpak through trade relationships with other Mackenzie Inuit groups, which despite the apparent territoriality of these societies, were also an important element of the Mackenzie Inuit socioeconomic system (McGhee, 1974; Betts, 2005, 2008, 2009). While this must remain a hypothesis for now, we expect that further research on the lithic landscape of the Mackenzie Inuit area in concert with an examination of the frequencies of different raw materials in other Mackenzie Inuit sites will further illuminate the social constraints and other factors that structured the procurement and circulation of stone in Mackenzie Inuit society. In addition, Thule sites in the
Mackenzie Delta region may hold clues that illuminate the historical development of these lithic procurement patterns, including the social strategies associated with the procurement of Thunder River chert.

\section{CONCLUSION}

Lithic quarries are immobile resources in ever-changing social landscapes, and thus it stands to reason that these places were areas of increased social interaction between different peoples in the past, especially in cases where exposures of high-quality lithic material were rare or unevenly distributed across the landscape. As demonstrated in this paper, the Thule expansion into the western Canadian Arctic and the subsequent development of a complex Mackenzie Inuit society in the Mackenzie Delta region ultimately led to a situation in which both Inuit and Dene groups used Vihtr'ii Tshik as a lithic source, and it is likely that all of these cultural groups had to adapt to these social circumstances. While the analysis presented in this paper benefited greatly from a relatively rich body of oral and written historical data that allowed us to reconstruct the social context of 
Inuit stone procurement from Vihtr'ii Tshik, in most cases this type of contextual information is not available, especially for the deeper past. Instead, the greatest strength of the archaeological record for understanding the role of social factors in shaping the lithic procurement practices of huntergatherer societies may be its diachronic perspective, and archaeologists should consider the possibility that changes in patterns of lithic raw material procurement through time may reflect changes to the social landscape.

The non-destructive polarized energy-dispersive X-Ray fluorescence (P-ED-XRF) method used for archaeological fingerprinting in this paper provided an effective approach for testing the hypothesis that the Kuukpangmiut obtained lithic raw material from Vihtr'ii Tshik. While ED-XRF has traditionally been used for sourcing obsidian and other volcanic rocks (Shackley, 2011b), recent studies show that it is also a useful method for establishing the geochemical signatures of cherts (e.g., Gauthier and Burke, 2012; this study), indicating that ED-XRF has the potential to be a versatile archaeological fingerprinting technique for a variety of raw materials. Most importantly, this analytical technique facilitates non-destructive analysis of large sets of samples and thus aligns well with the ethics of archaeological collection management.

\section{ENDNOTE}

The XRF geochemical data used in this study are available on request from LCMA. We would also consider lending the cut and polished quarry samples used in this study to any lab interested in continuing or expanding this sourcing research.

\section{ACKNOWLEDGEMENTS}

We thank Stacey Girling-Christie and Jean-Luc Pilon at the Canadian Museum of Civilization and Susan Irving at the Prince of Wales Northern Heritage Centre for facilitating our access to collections. We thank Ingrid Kritsch of the Gwich'in Social and Cultural Institute for sharing oral historical information about Vihtr'ii Tshik. We thank Amy Barker and Julie Buysse for creating the maps for the paper, and Alestine Andre, Tom Andrews, Ingrid Kritsch, David Pokotylo, and two anonymous reviewers for providing helpful comments on earlier drafts of the paper. As always, any errors or omissions are our own. Funding for this project was provided by the Prince of Wales Northern Heritage Centre.

\section{REFERENCES}

Andre, H. 1992. Gwichya Gwich'in Place Names Project 1992, Tape \#18, July 15, 1992. Unpubl. transcript available at the Gwich'in Social and Cultural Institute, PO Box 46, Tsiigehtchic, Northwest Territories, X0E 0B0.
Andrews, T.D., and Zoe, J.B. 1997. The Idaa Trail: Archaeology of the Dogrib cultural landscape, Northwest Territories, Canada. In: Nicholas, G.P., and Andrews, T.D., eds. At a crossroads: Archaeology and First Peoples in Canada. Burnaby, British Columbia: Archaeology Press, Simon Fraser University. $160-177$.

Andrews, T.D., MacKay, G., Andrew, L., Stephenson, W., Barker, A., Alix, C., and the Shúhtagot'ine Elders of Tulita. 2012. Alpine ice patches and Shúhtagot'ine land use in the Mackenzie and Selwyn Mountains, Northwest Territories, Canada. Arctic 65(Suppl. 1):22-42.

Arnold, C. 1986. Preliminary report on the 1986 activities of the Mackenzie Delta Heritage Project: Excavation at Gupuk. Unpubl. report available at the Prince of Wales Northern Heritage Centre, PO Box 1320, Yellowknife, Northwest Territories X1A 2L9.

1994. Archaeological investigations on Richards Island. In: Pilon, J.-L., ed. Bridges across time: The NOGAP Archaeology Project. Victoria: Canadian Archaeological Association. 85-94.

Bamforth, D.B. 2006. The Windy Ridge quartzite quarry: Hunter-gatherer mining and hunter-gatherer land use on the North American Continental Divide. World Archaeology 38(3):511-527.

Betts, M.W. 2005. Seven focal economies for six focal places: The development of economic diversity in the western Canadian Arctic. Arctic Anthropology 42(1):47-87.

- 2008. Subsistence and culture in the western Canadian Arctic: A multicontextual approach. Mercury Series 169. Gatineau: Canadian Museum of Civilization.

- 2009. Chronicling Siglit identities: Economy, practice, and ethnicity in the western Canadian Arctic. Alaska Journal of Anthropology 7(2):1-28.

Binford, L.R. 1979. Organization and formation processes: Looking at curated technologies. Journal of Anthropological Research 35(3):255-273.

— 1980. Willow smoke and dogs' tails: Hunter-gatherer settlement systems and archaeological site formation. American Antiquity 45(1):4-20.

Blair, S.E. 2010. Missing the boat in lithic procurement: Watercraft and bulk procurement of tool-stone on the Maritime Peninsula. Journal of Anthropological Archaeology 29(1):33-46.

Calogero, B.L.A. 1992. Lithic misidentification. Man in the Northeast 43:87-90.

Castonguay, R., comp. and ed. 2001. Chapter III: Toponoymic inventory. In: Savoie, D., ed. Land occupancy by the Amerindians of the Canadian Northwest in the 19th century, as reported by Émile Petitot: Toponymic inventory, data analyses, legal implications. Edmonton: CCI Press. 29-228.

Clark, D.W. 1975. Archaeological reconnaissance in northern Interior District of Mackenzie: 1969, 1970, and 1972. Mercury Series, Archaeological Survey of Canada Paper 27. Ottawa: Canadian Museum of Civilization.

Ellis, C. 2011. Measuring Paleoindian range mobility and landuse in the Great Lakes/Northeast. Journal of Anthropological Archaeology 30(3):385-401. 
Franklin, J. 1971. Narrative of a second expedition to the shores of the Polar Sea in the years 1825, 1826, and 1827. Reprint edition. Edmonton: M.G. Hurtig Ltd.

Friesen, T.M., and Arnold, C.D. 2008. The timing of the Thule migration: New dates from the western Canadian Arctic. American Antiquity 73(3):527-538.

Gauthier, G., and Burke, A.L. 2011. The effects of surface weathering on the geochemical analysis of archaeological lithic samples using non-destructive polarized energy dispersive XRF. Geoarchaeology 26(2):269-291.

Gauthier, G., Burke, A.L., and Leclerc, M. 2012. Assessing XRF for the geochemical characterization of radiolarian chert artifacts from northeastern North America. Journal of Archaeological Science 39(7):2436-2451.

Gwich'in Social and Cultural Institute. 2012. Gwich'in Social and Cultural Institute Place Names Database. Unpubl. database available at the Gwich'in Social and Cultural Institute, PO Box 46, Tsiigehtchic, Northwest Territories X0E 0B0.

Hanks, C.C., and Winter, B.J. 1983. Dene names as an organizing principle in ethnoarchaeological research. Musk-Ox 33:49-55.

Heine, M., Andre, A., Kritsch, I., Cardinal, A., and the Elders of Tsiigehtshik. 2007. Gwichya Gwich'in Googwandak: The history and stories of the Gwichya Gwich'in as told by the Elders of Tsiigehtshik, rev. ed. Tsiigehtchic, Northwest Territories: Gwich'in Social and Cultural Institute.

Hummel, M., and Ray, J.C. 2008. Caribou and the North: A shared future. Toronto: Dundurn Press.

Lamb, W.K., ed. 1970. The journals and letters of Sir Alexander Mackenzie. London: Cambridge University Press.

Le Blanc, R.J. 1991. Prehistoric clinker use on the Cape Bathurst Peninsula, Northwest Territories, Canada: The dynamics of formation and procurement. American Antiquity 56(2):268-277.

Lemieux, Y., Gal, L.P., Pyle, L.J., Hadlari, T., and Zantvoort, W. 2007. Report of activities on the structural geology of southern Peel Plateau and Peel Plain region, Northwest Territories and Yukon. Current Research (Online) 2007-A3. Ottawa: Geological Survey of Canada.

Loring, S.G. 1992. Princes and princesses of ragged fame: Innu archaeology and ethnohistory in Labrador. PhD thesis, University of Massachusetts, Amherst. 607 p.

Lundblad, S.P., Mills, P.R., and Hon, K. 2008. Analysing archaeological basalt using non-destructive energy-dispersive X-ray fluorescence (EDXRF): Effects of post-depositional chemical weathering and sample size on analytical precision. Archaeometry 50(1):1-11.

MacKay, G. 2010. Archaeological and ethnographic investigation of the Sambaa K'e cultural landscape. Unpubl. ms. available at the Prince of Wales Northern Heritage Centre, PO Box 1320, Yellowknife, Northwest Territories X1A 2 L9.

McCaffrey, M. 2011. Ancient social landscapes in the eastern Subarctic. In: Sassaman, K.E., and Holly, D.H., Jr., eds. Hunter-gatherer archaeology as historical process. Tucson: The University of Arizona Press. 143-166.

McGhee, R. 1974. Beluga hunters: An archaeological reconstruction of the history and culture of the Mackenzie
Delta Kittegaryumiut. St John's: Institute of Social and Economic Research, Memorial University of Newfoundland.

McLennan, S.M. 2001. Relationships between the trace element composition of sedimentary rocks and upper continental crust. Geochemistry, Geophysics, Geosystems 2(4):1021-1044, doi:10.1029/2000GC000109.

Meltzer, D.J. 1989. Was stone exchanged among eastern North American Paleoindians? In: Ellis, C.J., and Lothrop, J.C., eds. Eastern Paleoindian lithic resource use. Boulder, Colorado: Westview Press. 11-39.

Millar, J.F.V., and Fedirchuk, G. 1975. Report on investigations: Mackenzie River archaeological survey. Ottawa: Environmental-Social Committee, Northern Pipelines.

Mills, P.R., Lundblad, S.P., Smith, J.G., McCoy, P.C., and Naleimaile, S.P. 2008. Science and sensitivity: A geochemical characterization of the Mauna Kea Adze Quarry Complex, Hawai'i Island, Hawaii. American Antiquity 73(4):743-758.

Mills, P.R., Lundblad, S.P., Field, J.S., Carpenter, A.B., McElroy, W.K., and Rossi, P. 2010. Geochemical sourcing of basalt artifacts from Kaua'i, Hawaiian Islands. Journal of Archaeological Science 37(12):3385-3393.

Mintmier, M.A., Mills, P.R., and Lundblad, S.P. 2012. Energydispersive X-ray fluorescence analysis of Haleakala basalt adze quarry materials, Maui, Hawai'i. Journal of Archaeological Science 39(3):615-623.

Norris, D.K. 1984. Geology of the northern Yukon and northwestern District of Mackenzie, Map 1581A, scale 1:500,000. Ottawa: Geological Survey of Canada.

Pierce, K.L., and Jones, A.L., compilers. 2009. ArcGIS ${ }^{\circledR} 9 . x$ digital atlas to accompany regional geoscience and petroleum potential, Peel Plateau and Plain, Northwest Territories and Yukon: Project volume. Yellowknife: Northwest Territories Geoscience Office.

Pilon, J.-L. 1990. Vihtr'iitshik: A stone quarry reported by Alexander Mackenzie on the Lower Mackenzie River in 1789. Arctic 43(3):251-261.

Pokotylo, D.L. 1994. Archaeological investigations at Vihtr'iitshik (MiTi-1), lower Mackenzie Valley, 1992. In: Pilon, J.-L., ed. Bridges across time: The NOGAP Archaeology Project. Victoria: Canadian Archaeological Association. 171-192.

Pokotylo, D.L., and Hanks, C.C. 1989. Variability in curated lithic technologies: An ethnoarchaeological case study from the Mackenzie Basin, Northwest Territories, Canada. In: Amick, D.S., and Mauldin, R.P., eds. Experiments in lithic technology. Oxford: BAR. 49-66.

Richardson, J. 1851. Arctic Searching Expedition: A journal of a boat-voyage through Rupert's Land and the Arctic Sea, in search of the discovery ships under command of Sir John Franklin. London: Longman, Brown, Green, and Longmans.

Shackley, M.S., ed. 2011a. X-ray fluorescence spectrometry (XRF) in geoarchaeology. New York: Springer.

. 2011b. An introduction to X-ray fluorescence (XRF) analysis in archaeology. In: Shackley, M.S., ed. X-ray fluorescence spectrometry (XRF) in geoarchaeology. New York: Springer. 7-44.

Slobodin, R. 1960. Eastern Kutchin warfare. Anthropologica 2(1):76-94. 
Speakman, R.J., Glascock, M.D., and Steponaitis, V.P. 2008. Geochemistry. Chapter 5 in: Herbert, J.M., and Reynolds, T.E., eds. Woodland pottery sourcing in the Carolina Sandhills. Research Report 29. Chapel Hill: Research Laboratories of Archaeology, University of North Carolina. 56-72.

Stefansson, V. 1919. The Stefánsson-Anderson Arctic Expedition of the American Museum: Preliminary ethnological report. Anthropological Papers of the American Museum of Natural History 14(1-2). New York: The American Museum of Natural History.

1922. Hunters of the Great North. New York: Harcourt, Brace and Company.
Taylor, S.R., and McLennan, S.M. 1985. The continental crust: Its composition and evolution. Oxford: Blackwell Publishing.

Toews, S. 1998. "The Place Where People Travel": The archaeology of Aulavik National Park, Banks Island. NWT Permit \#97-00004. Unpubl. report available at the Prince of Wales Northern Heritage Centre, PO Box 1320, Yellowknife, Northwest Territories X1A 2L9.

Usher, P. 1971. The Canadian Western Arctic: A century of change. Anthropologica 13(1-2):169-183.

Walsh, M.R. 1998. Lines in the sand: Competition and stone selection on the Pajarito Plateau, New Mexico. American Antiquity 63(4):573-593. 